\title{
The Effect of the Electoral System on Political Representation in Iraq Post 2003
}

\author{
Mohammed Abed Hammadi ${ }^{1} \&$ Magda Ali Saleh ${ }^{2}$ \\ ${ }^{1} \mathrm{PhD}$ Candidate in Faculty of Economy and Political Science, Cairo University, Cairo, Egypt \\ ${ }^{2}$ Acting Dean, Faculty of Economics \& Political Science, Cairo University, Cairo, Egypt \\ Correspondence: Mohammed Abed Hammadi, Faculty of Economy and Political Science, Cairo University, \\ Cairo, Egypt. E-mail: Mohamd9.almsary@Gmail.com
}

\author{
Received: April 9, 2017 \\ Accepted: April 26, 2017 \\ Online Published: May 31, 2017 \\ doi:10.5539/ass.v13n6p149 \\ URL: https://doi.org/10.5539/ass.v13n6p149
}

\begin{abstract}
The study discusses the influence of the electoral system on the political representation of the social compositions of the Iraqi people, and the nature of their political participation in the ongoing political process in Iraq, by means of structuring entities and parties on basis of subsidiary identities, aside from the national identity. The study is divided into two research objectives. The first research objective is examining the nature of the political representation of the social compositions after the American invasion of Iraq in 2003, through exploring the religious and nationalistic diversities of the social compositions of the Iraqi society, in addition to discussing the political blocs and parties in the Iraqi system post 2003. The study realizes that these parties and political blocs depend on the sectarian and doctrinal dimension as well as the nationalistic ideology shedding its shadow on the entire political process. In turn, the political process employs quota systems as an approach towards its formation, which also brings about weak leadership and personnel loaded with personal gain against loyalty and citizenship. The second research objective is discussing the development of the electoral system and its effect on the representation of social compositions within the political process, through tracing three legislative elections taking place after 2003. The study reached several points of results, the most important of which is the influence of the electoral system on the political process and its effect on the nature of political representation of social compositions, since this system produces a majority out of a single composition at the expense of other social compositions in the Iraqi society. As a result, it gave rise to a house of representatives unable to fulfill its legislative and inspective functions, and that operates as a field for settling preset agendas and expressing authoritative judgments.
\end{abstract}

Keywords: Electoral system, Political systems, Political representation, State of Iraq

\section{Introduction}

One of the most important decisions in a democracy is the choice of an electoral system. In most cases, this choice results in a specific electoral system with crucial consequences to the future of the political life, since it is concerned with emergence of legislation authority through which the executive authority as well as the government will be structured. The process of choosing or changing electoral systems comes as a result of new variables in the political reality, such as a change in the political system from a single party to multiple parties, or state's independence. Sometimes, the political struggle arising in existing democratic systems causes a change in the established electoral system for the purpose of filling a gap or fixing a defect. Moreover, the agents supporting political reformations may place the issue of changing the electoral system in their political agenda as to improve the existing political system. Therefore, any transpiring democratic system needs to opt for a particular electoral system that fits the nature of society, in terms of sectarian and nationalistic diversities, and minorities, ensuring the participation of the majority of these compositions in the political decision-making and implementation.

\section{Political Representation in Iraq Post-2003}

\subsection{Religious and Nationalistic Diversity in the Compositions of the Iraqi Society}

Religious and nationalistic diversity is one of the components in the formation of a political system in Iraq at this stage, although it is considered one of the reasons behind political and social instability. This is due to the lack of 
concurrence among the social compositions that centered around subsidiary ethnic, nationalistic, and religious identities forming the Iraqi society (AbdAllah, 2010), as follows:

1. Arabs, the majority, form ( $75 \%-80 \%)$ of the population, divided into Sunni and Shiites.

2. Kurds form (12\%-18\%) of the population.

3. Turkmen living on the frontier strip between Arabs and Kurds where Turkmen represent an ethnic minority, they constitute about (10\%) of Iraq's population.

4. Christians divided among various churches, sects, and ethnicities, including (Assyrians, Chaldeans, Armenians, Syriacs). The majority of Christian Iraqis live in Nineveh Plains, Ankawa, and Shaqlawa.

5. Shabak, likely 10000-15000 people, the majority living in Nineveh Governorate.

6. Yazidis, an ethnic religious group, which historians did not agree on its origins. They live on various areas of North Iraq, but the majority settled in Nineveh Governorate, Sinjar Bashiqa, and Shikan cities. They speak Kurdish, and some speak Arabic.

7. Mandaeans live on the banks of the Tigris and the Euphrates rivers, south of Iraq. They speak their own language, and work in boat manufacturing, harvest machinery, and silver engraving. They believe their religion to be the oldest. They are estimated to be 16 million in population in year 1877 (Alkhyon, 2003).

Such diversity in the Iraqi society affects the political infrastructure of the Iraqi political system through the creation of political diversity, negatively influencing the establishment of the modern nation. However, this does not mean that social diversity is negative per se. Yet, there is a huge challenge in crystalizing a political formula that would allow such diversity to become a source of power through equal participation in the political life, governed by an electoral system that guarantees the rights of every social composition. The sectarian and nationalistic diversity formed one of the most important obstacles in building a democracy in post-2003 Iraq, due to the lack of accord between the compositions and the increase in the divisions caused by such diversity. One of its most observable manifestations is the ferocious conflict arising after the fall of the previous regime.

One of the most important negativities of ethnic diversity in Iraq is dividing the political and social infrastructure into subsidiary identities serving particular social groups, which makes fusion and reconciliation hard to reach. In addition, such diversity stands against completion of national synthesis, and the creation of national unity depended on national political identity represented in citizenship as the highest value protecting the dignity and status of all religious and nationalistic diversities.

Iraqi compositions blend, overlap, and incorporate together clearly through shared bonds, "the nationalistic division of society into Arabs, Kurds and Turkmen offers an alliance of a different kind. Turks, for example, are divided into Shiites and Sunnis. Shiite Kurds share doctrine with Shiite Arabs and Shiite Turkmen. The same goes for the Sunni Kurds who connect through doctrine with the Sunni Arabs and Turkmen" (AlKaabi, 2012). These religious or doctrinal bonds give rise to other bonds through marriage of the same doctrine among various ethnic groups, which positively strengthens the bonds between groups forming the Iraqi society sharing Islam as a religion. On the other hand, non-Muslim groups, such as Christians, Yazidis, and Mandaeans, are integrated culturally, socially or through jobs, sharing among them national, social and historical interests, and leading to deepening the relationships between compositions of a single society.

The alienation and marginalization suffered by individuals, or ethnic or sectarian group become the reason for their reliance on external forces to fortify their endeavor towards earning back their rights and battle such alienation and marginalization. This process opens the door for the intervention of external forces in internal affairs of countries with various ethnicities, sects, and doctrines, especially during transitional periods through which societies go from oppression to democratization. Such external factor may feed the existing difference to the point of conflict between society's compositions. This can be seen in Iraq after the American invasion. As means to earn the rights of distressed sects and minorities suffering under the previous regime, the attraction and inclination towards the external forces- represented in the occupation and regional powers- becomes one of the most important factors leading to the increased influence of the external forces on the changes taking place in Iraq after the downfall of its regime in 2003. For instance, occupational forces deepened on the sectarian and ethnic differences to reformulate the political system following the invasion, on basis of sectarian and ethnic quotas. As a result, the compositions of the Iraqi society have become entrenched in their subsidiary identities to the point that citizens would try to find refuge in civil institutions, whether tribal, sectarian, or ethnic, to find personal or social protection, away from the state and its institutions (Mohamed, 2012).

The post-2003 period witnessed a deep setback in civilization relapsing Iraq to the pre-establishment era, and 
that is clear in the destruction of the social infrastructure of the Iraqi society, the downfall of values and moral standards, the dilution of social solidarity, and the rise of sectarian and ethnic conflicts. This can be attributed to many reasons including,

1. The variation, diversity, and differences in the social and cultural compositions, beginning with ethnicity, religion, and language, and concluding with tribes and sects.

2. The variation of allegiances and alliances, each attracting social devotion around itself

3. Patriarchy that dominates the intellectual and social infrastructure, on which relationships and consanguinity are built, connected with values, customs, and tribal and sectarian coalitions. Those elements still practice their influence on individuals and their behaviors, as well as on the value system, code of conduct, and social relationships (Al-Haidary, 2009)

4. Internal and external wars ushered by the previous regime, as well as the economic siege burdening the entire society with its problems, had their negative effect on the social fabric in general, adding to this the transition from nationalism to sectarianism and shelving citizenship

5. The American invasion of Iraq in 2003 led to the collapse of political, security, social and economic institutions, which formed the proper environment for extremist terror movements to practice their acts of terrorism and proliferate, in the absence of repressive security forces, creating safe havens for themselves inside Iraqi cities (Da'een, 2014)

6. External interventions played a vital role in feeding violence in Iraq, which serves its agenda and interests, resulting in Iraq becoming an open field for the conflict of regional powers with Iraqi tools

7. Authoritarianism and totalitarianism enforced by Islamism affected the social behavior

8. The democratic chaos, experienced by society after the invasion, created political instability and had negative results causing the dissociation of the social fabric

9. Proliferation of violence and power caused the emergence of militias associated with influential political parties which also had its role in dissociating the social fabric

As a result, some leaders of ethnic, religious, tribal, sectarian and other social components have managed to exploit this "turbulent transitional period in which Iraq is going through and to exercise various methods to redefine its components on a sectarian and ethnic basis to assert its sub-identity and achieve its sectarian interests" (Mohamad, 2012) which weakened the national identity and led to the eventual failure of political elites in the crystallization of social consciousness based on the construction of the real democratic system.

\subsection{Political Parties in the Iraqi Regime after 2003.}

The legislation that organized the political process in Iraq after 2003 helped to promote the phenomenon of multi-partyism such as the Iraqi State Administration Law, the Political Parties and Organizations Law No. 97 of 2004, and the Elections Law No. 96 of 2004 through the system of proportional representation, which effectively contributed to the arrival of large numbers of parties to the parliament and the freedom to form and join trade unions and parties which in accordance with the law is a guaranteed right. The Constitution of Iraq, in 2005, also affirmed the same content when it stipulated the freedom to form associations and political parties, and to belong to them provided that they are regulated by law. However, the delay in the adoption of the parties' law contributed to the disruption of the political scene, as well as the great influence of proportional representation system adopted by the repeated election laws after 2003. This led to the participation of large numbers of entities and political parties in the electoral process and the exit of large numbers of parties without any gains in light of the ethnic and sectarian polarization revealed by the elections that took place after 2003 (Jameel, 2007) to (269) political party under various names (party, movement, current, and assembly), while the number of parties represented in the House of Representatives reached (26) parties only, and in the parliamentary elections On March 7, 2010, the number of political parties and forces reached 256. The number of parties that joined the House of Representatives was 36 political entities.

The most important features of the Iraqi political parties during this period:

1. Most political parties present in the Iraqi political arena are weak and vulnerable because of the weakness of their popularity bases. Their leaderships are unknown to the majority of Iraqis as well as their intellectual frameworks and organizational structures. That is why most of these parties are merely extensions of tribal, sectarian, and ethnic formations (Abdullah, 2005).

2. Some of the old parties did not offer what suggests that they are working to renew themselves or to evaluate 
their experience and continued to suffer from divisions and dispersion. They have not been able to communicate with their former public bases, especially as some of them reflect old or no longer existing social strata, as is the case with the National Democratic Party (Naseer al-Jaderji), Umma Party (Saad Saleh Gaber), Nasserist parties and Independence Party. They are all parties from the 1950s (Jameel, 2007).

3. Most parties suffer from a lack of awareness of the axioms of political scientific thought due to the existence of semi-educated and adventurous persons, which results in the spread of ignorance. In addition, politics is described as the art of managing the affairs of the state and society but not accessing to power, resorting to investment and cheap profit, or compensating for various models of inferiority complex (Al Janaby, 2009).

4. Most political parties and entities are seeking personal interests and are spinning in the orbit of their founders. Moreover, they are based on the idea of the sanctification of the party's chairman or relying on a few historical leaders of the party. To illustrate, political parties and blocs, formed in parliament, depend on one character who eventually becomes the sole representative of the party. This was negatively reflected on the political performance. It even becomes a hostage to the personal aspiration of its founder gradually losing its organizational content. Furthermore, its main objective is to have access to power. This is a sustainable and dynamic conflict that weakens the ability of institutions to move forward and move strategically (Jaber, 2009).

5. Most of these parties were not established on a national level regarding form and content, but in accordance with a class structure (regional, tribal or sectarian) (Gabr, 2007).

6. Several political parties and forces fall under the category of "structural parties", which consist of a structure formed by the party's limited cadre. It also lacks a popular base. This was confirmed by the elections' results, when a large number of parties and entities came out with little results which prove their weak influence on voters, a phenomenon which requires a reassessment of the role of these parties and forces in political life (Saleh, 2010).

\section{The Evolution of the Electoral System in Iraq Post-2005}

The developments after the fall of the Iraqi regime have resulted in a clear political movement that opened the door for the establishment of various political movements and organizations in the Iraqi political arena represented in parties, organizational structures, and some other various entities, whether Islamic or secular entities. Some of them carry only the party's name, some have popular bases and many others miss all that. Therefore, some of them are known to the Iraqi street and have a long history and experience in the field of political work and in the ranks of the opposition and some did not appear until after 2003.

During the period from 2005 to 2014, there were three parliamentary electoral processes; each stage is different from the following in terms of the participation of political entities, the form of the electoral system, and the proportions of political representation agencies:

\subsection{Legislative Elections}

After 2003, Iraq entered a period of imbalance in political and social construction due to the shift of the political and social decision-making center from the one-party system, which used all the social, economic, and political data to ensure its permanence and survival in power, to a modern system based on democracy and parliamentary system. Political opposition to the former regime of this process of change was able to control the political and social situation of Iraqi society through the restructuring of society on sectarian and national bases and made use of the tendencies of the majority within the spectrum of Iraqi society to impose its ideology and policy. As a result, a serious issue, that plays a large role in the future of Iraq, has emerged which is the proportion of sectarian and sectarian structure of Iraqi society, and that is also due to the absence of official and accurate statistics of the demographic structure in Iraq in terms of the real proportions of the Iraqi components. There is a wide difference between the sources in this regard; there are those who claim that the Sunnis, Arabs and Kurds and Turkmen make up only (38\%) of the Iraqi population and that the Sunni Arabs represent only (19\%) of Iraqis. This is evident after the occupation during the formation of the Interim Governing Council of 25 seats when the Sunni Arabs were given five seats only and were considered a minority. There is an important issue that should be taken into account that no actual census has been performed in Iraq from 1920 up till now which includes the sectarian aspect. All censuses since 1919 were based on counting the number of people in each province. On the other hand, in the 2005 elections Harith al-Dari (Secretary General of the Association of Muslim Scholars) of the Sunni component issued a fatwa prohibiting the participation in the elections. That was the reason behind the reluctance of Sunni citizens to take part in those elections (International Crisis Group, 2009). This gave the opportunity for the other Iraqi components to replace the Sunni component because of this fatwa, which turned the Sunnis into a minority in the composition of parliament and government. This gave the opportunity for the 
other Iraqi components to replace the Sunni component in filling the void left by this fatwa, which made them a minority in the composition of parliament and government.

In 2005, the House of Representatives consisted of 275 seats, 230 seats of which were allocated to constituencies and 45 compensatory seats, and the proportional representation system was adopted. The law adopted the closed list system, which requires voters to vote on all the names on the list. The Electoral Commission announced on December 20, 2005, the preliminary results of the parliamentary elections with the victory of the United Iraqi Alliance by $58.6 \%$ of the votes counted in Baghdad, which were estimated at $89.5 \%$ of the total votes. Iraq's Accordance Front came second after winning $18.78 \%$ of the votes, and then the Iraqi List with $14 \%$.

Iraq's Accordance Front ranked second with $18.78 \%$ of the vote, and then the Iraqi List with 14\%. On January 20 , 2006, the Commission announced the final results where the United Iraqi Alliance won 128 seats, the Kurdistan Alliance won 53 seats, the Accordance Front 44 seats, the Iraqi List 25 seats, the National Dialogue Front 11 seats, the Kurdistan Islamic Union 5 seats and the List of Reconciliation and Liberation 3 seats, the List of Correspondents 2 seats, and the List of the Christian Rafidain, the Turkmen of Iraq and the Yazidis and the list of Mithal Alosi each with one seat (Arabic Strategic Report, 2006).

Accordingly, most components of Iraqi society got a representation within the dome of parliament, but it was in varying proportions and has no effect in the political decision because of a significant difference in the proportion of representation between these components, especially after using the Closed List system.

\subsection{Legislative Elections}

The divisions between the political forces led to the development of the map of alliances between them. Perhaps the most important feature was the disintegration of entities and large forces that were formed on a sectarian basis in the 2005 elections, when forces emerged based on national programs away from sectarian and ethnic quotas, as well as the interactions between those forces. There are about 12 alliances and 86 parties of 297 political parties registered to enter the parliamentary elections with the Commission (Salem, 2010). There were 6218 candidates, including 1798 female candidates. The most prominent competing lists, which represent the major components of Iraqi society are the State of Law Coalitions, the Iraqi National Coalitions, the Iraqi National Movement, the Iraqi Unity Union and the Kurdistan Alliance (Hassan, 2011). It is noted that most of the Coalitions formed were major parties with political and social background. Some disputes and consensus have been made to build new alliances on the basis of interpersonal relations among the leaders, making the voting style of the coalition based on the personality of the coalition leader and not on his political program (Abdulqader, 2010). The preparatory period for the Council of Representatives elections was characterized by disagreements and divisions between political entities and parties on its position of the new legislation for elections or amending the previous Law No. (16) of 2005, or to maintain it. However, there are number of reasons that led to the process of amending the law, the most important of which is the demand of the Supreme Leader Ali al-Sistani and on more than one occasion of the need to adopt the Open List system and multiple constituencies as it provides a greater opportunity for the voter to choose who to represent him in the House of Representatives (Hassan, 2011). The second reason is the demand of civil society organizations and intellectuals from the strata of Iraqi society that the elections should be conducted in accordance with the system of Open List and multiple constituencies, as it is reached from the previous elections that the voter realized that the adoption of the Closed List and the sole electoral constituencies is good for the political units and parties participating in the elections. After long discussions between the political parties, Parliament was able to adopt the Election Law No. 26 of 9/12/2009, which amended the electoral law No. 16 of September 2005, depending on the law of St. Lego in the distribution of parliamentary seats, as the percentage of population was calculated according to the statistics of the Ministry of Commerce for the governorates in 2005, in addition to the rate of population growth rate of $(2.8 \%)$ for each governorate. Accordingly, the parliamentary seats for each governorate have been determined, plus the compensatory seats, so that the total seats reached (325) seats of the House of Representatives. According to law, the number of Iraqi citizens reached (32.5) million people, and that voting had to take place through the open constituencies. The voter may choose the person deemed appropriate with the number of the entity, taking into account that Iraq is divided into (18) constituencies according to the administrative borders of each governorate. The quota of seats had to be allocated to the electoral constituencies in proportion to the population size of each constituency. Elections would be held under the representation system. The seats were divided on the parties according to the number of votes they gained in every governorate according to the Election Law No. 26 in 2009. The seats were divided by (310) seats on governorates with (8) seats for minorities and (7) compensatory seats, with the proportion of women $(25 \%)$ of the seats. Provincial seats have been allocated on the basis of the population density in each governorate, ensuring the share of the minority and therefore the provincial seats varied among them, as Baghdad governorate share reached (68) seats 
in addition to the seats of the Christian component and another seat of the Mandaean Sabean component, the province of Nineveh got (34) seats, including three seats for each of the Christian components, Yazidi and Shabiki. Basra ranked third with 24 seats, and the province of Dhi Qar got (18) seats, while the province of Sulaymaniyah got (17) seats, and Babel got 16 seats and Erbil governorate got 15 seats, including one seat for the Christian component. The share of Anbar province reached (14) seats, and the share of Diyala and Kirkuk reached (13) seats each, and each of the province of Salah al-Din and Najaf won (12) seats, while the provinces of Wasit, Qadissiya, Maysan and Dahuk got (11) seats each. Karbala won (10) seats, and finally the province of Muthanna got (7) seats.

The results of the parliamentary elections announced by the Independent Electoral Commission on 26/3/2010, led to the victory of fourteen political parties out of the sixty-eight political parties that participated in the elections. The number of parties that did not win seats reached (72) parties and the number of candidates participating in the elections reached (6234); (4428) males and (1806) females. The number of winning candidates reached (325) persons; (243) males and (82) females.

As for the number of seats for each Union, the Iraqi List got 91 seats, followed by the list of State of Law coalition, which won 89 seats. The Iraqi National Coalition came in third place with 70 seats, and the list of the Kurdistan Alliance got 43 seats. The List of Reconciliation got 6 seats, the List of Change got 8 seats, the Islamic Union got 4 seats, the unity of Iraq got 4 seats, Rafidain List got 3 seats, the Islamic Community and the People's Assyrian Chaldean Syriac got two seats each, while the Yazidi Movement for Progress and Shabki Reform Mohammed Jamshid got one seat each. The independent candidate Khaled Amin Roumi also got one seat (Hassan, 2011).

The 2010 elections showed the split and variations in the attitudes of the Iraqi voters. After the Islamic, National and Kurdish Movements were controlling the parliament by (66.5\%) for Islamists, (19\%) for Kurdish, (0.7\%) for Christianity and $13.8 \%$ for liberalism, the equation in the 2010 elections showed a marked decline in the Iraqi voters who tended toward sectarianism, nationalism and racism. The Islamic parties got (48.30\%), the Kurdish Nationalist List got (13.23\%) of the seats in the parliament, and the liberal lists got (38.47\%). It is a significant proportion about the change towards liberalism, and if the 2005 elections were characterized by sectarianism, then 2010 elections were characterized by a national coup against religious parties, as evidenced by the victory of the list led by Shiites in all Sunni provinces, and the popular decline witnessed by the religious parties in Iraq, whether Sunni or Shiite, while the Kurdish parties maintained their focus on their nationalism (Al-Sherifi, 2010).

We must not rule out the idea that the sectarian and ethnic aspects are main determinants in the Iraqi elections due to the closure of Iraqi society and its tribal nature and its clinging to the roots of sectarianism and nationalism that have been expressed through the tendency of the Iraqi voter to religious and nationalist parties. However, the 2010 elections produced a clear exception in this rule through the emergence of a secular party, embodied by the Iraqi List, which won the votes of Sunni Arabs and secularists. It got 91 seats, and a large part of the votes obtained by the Iraqi List was a result of an expression of protest against corruption and political sectarianism (Kubaisi, 2010). This leads to an important fact that "the Iraqi people did not want to have full confidence in a political party or coalition or a particular leader, but it distributed its choices among most political forces in varying proportions reflecting the sharp division over these unions, parties, electoral lists and political leaders" (Edriss, 2010).

The results also showed a keenness and direction to change, which means that there is a state of reluctance and rejection for the former Council. This concern for change was evident in the victory of the list of Iyad Allawi in the first place, and the coalition of Nuri al-Maliki in second place. Moreover, the Iraqi society imposed the national project on political forces to adopt in their election programs, speeches and slogans in the 2010 elections.

The results of these elections indicate the impact of the electoral system on the political representation of social components and the great difference between them and the system adopted in the 2005 elections.

\subsection{Legislative Elections}

The number of political entities representing the components of the Iraqi society participating in the electoral process in 2014 was (277) political entities, some of which joined (36) political coalitions, to compete for the seats in the Iraqi Council of 328 seats, including (8) seats for minorities from Iraqi components, with five seats for Christians distributed in the provinces (Baghdad, Nineveh, Irbil, Dahuk, Kirkuk), and a seat for Mandaean in Baghdad province, a seat for each of the Yezidi and Shabki component in the province of Nineveh. The number of entities that got seats in the Iraqi House of Representatives is (44) entities and political coalitions distributed in the provinces of Iraq in varying proportions. The Iraqi House of Representatives decided at its meeting held 
on 4/11/2013 to vote on the Draft of the Elections Law No. (45) of 2013, which adopted the St. Lego rate system. After difficult negotiations and many pressures from different local and international powers to enforce its legislation before the appropriate time of the next election date, which adopted the following:

1. Proportional representation system.

2. The open list, and having (18) constituencies according to the administrative borders of each governorate. The seats were allocated to the electoral constituencies in proportion to the population density of each constituency. The voter can select a list and one candidate from the selected list.

3. Increasing the number of seats, as stated in Article (11) of the law: The House of Representatives consists of (328) seats, with (320) seats distributed to the provinces according to administrative borders, and (8) seats, including quotas of components.

4. The modified St. Lego system, which was included in paragraph 14 of the Election Law, the method of allocating seats on the competing lists, which will be used to calculate the election results, based on the difference in the electoral denominator by dividing the correct votes of the competing lists against serial numbers $(6,1,3,5,7,9 \ldots)$. This distribution is considered a regression from the basic method of St. Lego, which divided numbers into $(1,3,5,7 \ldots)$ only because it gives a preference for large lists than small lists. Lawmakers in the Iraqi parliament have increased the number not only to 1.4 , but they create a higher number that was not used before in any parliament and made it 1.6 to ensure an increase in the loss of seats of small parties, in order to calculate the large political union influential in the government and parliament, ensuring that no significant change shall be made in the next elections.

5. Allocating $25 \%$ of seats for women.

In general, the following observations can be made about this election and its results:

1. The 2014 elections were the first parliamentary elections that took place after the departure of the occupation forces from Iraq. There was real change. Rather, it imposed a reality for a political process based on sectarian and ethnic foundations that led to sectarian strife and security deterioration that would lead to civil war (Al-jaboury, 2014)

2. The elections were accompanied by a dangerous security situation, especially in the areas where the Sunni component was present. It represents a battle between terrorist groups and Iraqi army forces, especially in Anbar province. The situation developed after that to include all Arab Sunni regions that the government lost control of.

3. Mr. Haider al-Abbadi becames the prime minister and the central treasury was empty containing only six hundred million dollars, whereas there had been huge budgets in the previous years that amounted to 150 billion dollars. No one until today can know where these billions went.

4. From the results of the 2014 elections, we find that there are splits between the three major parties that dominated the Iraqi political scene in the 2010 elections, the mass of the National Coalition with a Shiite majority, the Iraqi List of the Sunni majority and the Kurdistan Alliance of Kurdish nature, as follows: -

- We see that the Shiite component represented in the 2010 elections by the National Coalition, which includes the three main Shiite unions (the coalition of the State of Law, the mass of the Liberals and the mass of the citizen) was keen on keeping the Shiite component unified and was able to form the government headed by Nuri al- Maliki in spite of all the difficulties encountered(Hassan, 2014).

- In the 2010 elections, we see that the Sunni component of the Iraqi List, which received votes from majority of the Sunni component, including Shiite and secular characters came first in the results, but it quickly declined due to the lack of cohesion between its characters and the impact of the process of encouragement and intimidation used by some leading parties against some candidates, which led to the creation of Union Bloc headed by the former president of the Parliament, Osama Al- Negievy, which is the largest Sunni bloc after attracting Sunni leaders from other parties. At the same time, Iyad Allawi's did not change his project of trans-sectarianism and formed the national bloc, which included secular figures and technocrats. He participated in the elections despite the persistence and dominance of sectarian, tribal and nationalism parties.

- The Kurdish component did not enter these elections in a unified list in most areas with a Kurdish majority, even in the disputed areas, which were always united, because of the crisis of differences over the formation of the Kurdistan Regional Government, which emerged in the parliamentary elections in September 2013, 
and led to the rise of the Change Party led by Nushrwan Mustafa, and the decline of the Patriotic Union of Kurdistan led by former President Jalal Talabani.

5. The use of the St. Lego system in the calculation of votes and the distribution of parliamentary seats increased the loss of the seats of small parties for the large political blocs in power in the government and the parliament, as they formulated the appropriate method to count the votes and the distribution of seats in the electoral system that voted on it, which denies the occurrence of a significant change in the next elections (Mohamad, 2013).

6. After 2003, Iraq adopted the model of consensual democracy, which is the most viable system for multi-identity societies that have not succeeded in melting into a single nation. This has not happened in Iraq since 2003 up till now, and compatibility has become a tool for exclusion and sectarian strife. In the 2014 elections, no attempts were made to overcome this reality and to build a trans-sectarian coalition through genuine and serious dialogue between entities and coalitions that had been preoccupied with their divisions (Arabic Center for Researches and Policies Studies, 2014).

\section{Conclusion}

The study has reached many conclusions, the most important of which are:

1. The electoral system has an effect on representing all ethnic and racial components and minorities in parties. It managed to ensure parliament seats in satisfying percentages through adopting the quota representation which simultaneously and effectively contributed to establishing sectarianism and racialism, as it was conducted under circumstances when the Iraqi society was overwhelmed by sectarian congestion and denominational conflict. That led the electors to vote on a denominational-identity basis, not on national-identity basis. Thus, election was conducted based on bigger quotas for the major blocs at the expense of the minor blocs, applying Saint Lego amended law.

2. The electoral system has an influence on the political behavior of the executive authority that was formed, as a result of winning the largest number of parliament seats. That encouraged the former Prime Minister, Nouri Al-Malki, to call for constituting a majority government, apart from the other political blocs and bodies. That was rejected by most participating bodies, and it was considered an autocracy by one social constituent, ignoring the other elements and disregarding the introduction of a comprehensive national project including all categories of Iraqi people. Therefore, each electoral list adopted the interests of the group it represents, which enhanced the racial and denominational strain among the Iraqi people's categories. Thus, the electoral system became in this case a factor of discrimination.

3. The electoral system adopting the quota system in Iraq, as well as the existence of other supplementary factors, such as the multiplicity of racial, ethnic, cultural political denominations prevailing in the Iraqi society aggregately, led to a significant increase of the number of parties, as well as the heterogeneity of their intellectual ideologies and attitudes. This is viewed as natural, compared to the parties that worked with the opposition elements against the previous regime which resulted in severe conflict for reaching authority and achieving political advantages, which, as a result, disturbed political life and converted them into powerless parties. Thus, the influence of the party's role became much stronger than the constitutional authorities' role in managing the country affairs.

Based on the aforesaid conclusions, the study set a number of recommendations that may modify the course of the electoral system, the democratic process and the political situation. They are as follows:

1. Launching the process of amending the Constitution, particularly the ambiguous and obscure articles that imply doubled interpretation and permanently require interference by the Federal Court to judge and decide therein and to settle the consequent and arising dilemmas, since the Constitution became a stand, upon which all controversies among political blocs are hanged.

2. Achieving national reconciliation through turning the page, holding serious dialogues among conflicting political parties, settling crises, accepting visions and other opposed visions, with no exclusion or diminution of any social elements or political bodies, as well as proposing the prospective of each constituent or entity on how to achieve national reconciliation, achieving political agreement among the adversary parties and putting into effect the political reform document. Furthermore, expanding bridges of trust and cooperation among political entities for maintaining the political process to achieve security in the country.

3. Disbandment of the current commissariat, and constituting another elections commissariat, apart from the denominational and political quota, to ensure its fairness and independence in its work (reconsideration of 
the commissariat regulations, particularly those related to nominating the council of commissioners). This is what was called for by Mr. Muqtada Al-Sadr, along with a number of political parties, and its work should be under UN supervision and patronization in each substantial component of the commissariat.

4. Setting a new electoral system, in harmony with the national and denominational multiplicity of the Iraqi society. It shall ensure the participation of all entities and elements in the political process, and prevention of predomination by major political entities over the minor entities' rights. As well, it shall include a system for a fair and unbiased distribution of seats, with no injustice of any constituent.

5. Establishing the Principle of Citizenship and loyalty to the homeland, as well as building the state of real organizations, apart from partiality and personalizing the state in a certain party or character. This shall be implemented through adhering to the Constitution and implementing law, with no passing over law, whatever his political authority, personal capacity or the position he holds.

6. Incorporating a curriculum for electoral cultivation and education into the educational curriculum in schools and colleges, aiming at enlightenment and cultivation of society on the importance of the electoral process and how to choose among the candidates, as well as the foundations upon which the choice is based and the qualities that each candidate should have to achieve the aspirations of the community to be represented by him. Thus, the one-party monopoly or predomination over the state destines shall disappear and thus reach peaceful coexistence among the components of the Iraqi society.

\section{References}

Abdullah, A. A. \& Ibrahim, H. T. (2005). Present and Future of Democratic and Constitutional Choice in Iraq, Democratic Transformations In Iraq: Restrictions And Opportunities, Dubai: Gulf Research Center.

Abdullah, A. A. (2010). Third World Between National Unity \& Democracy (1st ed.). Baghdad: Public Cultural Affairs House, Studies' Series.

Abdulqader, M. (2010). Iraqi Political Entities And Elections Issues, Al-Ahram Strategic File. 182, $15-16$.

Al-Haidary, I. (2009). Social Constituents \& Iraqi Identity Dilemma, Abstract of the research submitted to the 1st Intellectual Forum For National Conversation, Baghdad, from 3-2 October.

Al-Jaboury, S. (2014). The Stable And Transformed In Iraq Elections Between 2010 \& 2014. Retrieved from http://www.kitabat.com/ar/page/12/04/2014/26223/.html

Al-Janabi, M. (2009). Iraq: Dialogue Of Alternatives, Baghdad: Masr Mortada Est. For Iraqi Book.

Al-Ka'abi, A. S. (2012). Map of Diversity and Multiplicity in Iraqi Society And Its Role In Forming The Political Map. El Hewar Al Motamedin site. Retrieved from http://www.ahewar.org/debat/show.art.asp?aid=326986

Alkhyon, R. (2003). Religions and Doctrines in Iraq (1st ed.). Publisher, Al-Jamal Kolonia.

Al-Kubaisi, Y. et al. (2010). The Iraqi Elections: Any New Political Map, Oman: Scientific Forum conducted by Alquds Center For Political Studies, Retrieved from http://www.alqudscenter.org.

Al-Sherifi, A. (2010). Iraq Elections 2010 Overcame Sects And Fell In nationalism. Alwasatnews site. Retrieved from http://www.alwasatnews.com/news/381054.html

Arabic Researches \& Policies Studies Center (2014), Iraq Elections 2014: Dedication Of Denominational Discrimination By Political Rntities, from http://www.dohainstitute.org/release/741671c6-a25c-4730-906b-dfff9be0514c

Da'een, E. K. (2014). National And International Violations Of Human Rights: Iraq As A Model (Unpublished Master Thesis). Denmark: AOU.

Edriss, M. A. (2010, March 21). Iraq And Political Choices' Crisis, El Khaleg El Emiratia Newspaper. Retrieved from http://www.alkhaleej.ae/portal

Gabr, S. (2007). Islamic Parties In Iraq: From Authority To Democracy (Islamic Iraqi Party As A Model), Madarek Magazine. 185-187.

Hassan, A. M. (2011). Intercommunications Of Political Entities In Iraqi Parliament Elections, (2005 - 2010), (Unpublished Master thesis). Cairo: Arabic Researches \& Studies Institute Arab States.

Hassan, H. (2014). Parliament Battle: Playing With Polarization Cards In Iraqi Elections, Al-Jazeera Studies Center, Retrieved from http://studies.aljazeera.net.

International Crisis Groups (2009, January 27). Iraqs Provincial Elections:The Stakes,Middle East Report, 82. 
Jaber, J. H. (2009). Conflict of State \& Identity In Iraq, In Democratic Transformation Dilemmas In Iraq, Scientific Forum Research, Magazine of Iraqi Association For Political Sciences, Faculty of Political Sciences.

Jameel, A. (2007, No. 7). Development Of Political Parties In Iraq, Madarek Magazine, Madarek Center For Researches \& Studies, 81-84.

Mohammed, H. A. (2012). Iraqi National Identity Dilemma, International Studies, 1-8. Retrieved from http://www.iasj.net/iasj?func=fulltext\&aId=72346.pdf.

Mohammed, H. A. (2013). Electoral System In Iraq: Sante Lego Method \& Sante Lego Amended Method, International \& Strategic Studies Center. Retrieved from http://cis.uobaghdad.edu.iq.

Saleh, N. M. (2010). Future of Party System In Iraq. Political Sciences Journal, 41, 297-300.

Salem, A., (2010). Iraqi Elections 2010: What's Up ? International Politics. 180.

The Arabic Strategic Report, (2005-2006). 337-338.

\section{Copyrights}

Copyright for this article is retained by the author(s), with first publication rights granted to the journal.

This is an open-access article distributed under the terms and conditions of the Creative Commons Attribution license (http://creativecommons.org/licenses/by/4.0/). 